\title{
THE STORY OF FOUNTAIN: \\ HARD FACTS AND SOFT SPECULATION
}

\section{Thierry de Duve}

\begin{abstract}
Thierry de Duve's essay is anchored to the one and perhaps only hard fact that we possess regarding the story of Fountain: its photo in The Blind Man No. 2, triply captioned "Fountain by R. Mutt," "Photograph by Alfred Stieglitz," and "THE EXHIBIT REFUSED BY THE INDEPENDENTS," and the editorial on the facing page, titled "The Richard Mutt Case." He examines what kind of agency is involved in that triple "by," and revisits Duchamp's intentions and motivations when he created the fictitious R. Mutt, manipulated Stieglitz, and set a trap to the Independents. De Duve concludes with an invitation to art historians to abandon the "by" questions (attribution, etc.) and to focus on the "from" questions that arise when Fountain is not seen as a work of art so much as the bearer of the news that the art world has radically changed.
\end{abstract}

KEYWORDS,

Readymade, Fountain, Independents, Stieglitz, Sanitary pottery

Then the smell of wet glue!

Mentally I was not spelling art with a capital A.

- Beatrice Wood ${ }^{1}$

No doubt, Marcel Duchamp's best known and most controversial readymade is a men's urinal tipped on its side, signed $\mathrm{R}$. Mutt, dated 1917, and titled Fountain. The 2017 centennial of Fountain brought us a harvest of new books and articles on the famous or infamous urinal. I read most of them in the hope of gleaning enough newly verified facts to curtail my natural tendency to speculate. But newly verified facts are few and far between. For example, I learned from Michael Taylor-and that's about it—that it is not Duchamp, as I thought, but rather Henri-Pierre Roché who appears as a ghost in the photo that shows the urinal hanging from the lintel of a doorway in Duchamp's studio, on West 67th Street, in Manhattan (Fig. 1.1). 2 The wall text in the 100th anniversary show of Fountain at the Philadelphia Museum of Art added that Roché also took the 
photo. The apparition is certainly compatible with the subject of the photo setting the camera on time exposure, running to take his place in the frame, and running back to deactivate the shutter. I can see Duchamp doing that, but why would Roché do it? Why the complicated "selfie" technique if Duchamp was present? And what was Roché doing in Duchamp's studio if the artist was absent? You see, I am forced to speculate even as I would be grateful to Michael Taylor for offering me hard factual evidence. ${ }^{3}$

Barring still undiscovered hard facts, William Camfield's rigorous study of the Fountain-dossier, which dates from the late eighties, remains the soundest basis on which all of us Duchamp scholars must rely and then speculate. ${ }^{4}$ Since speculate I cannot avoid, let me start from the only fact that perhaps qualifies as a hard fact when we speak of the R. Mutt affair, the existence of the second issue of The Blind Man and, in it, the double page that informs the world that a controversy involving a urinal has shaken the Society of Independent Artists the day before its first show was scheduled to open, on April 10, 1917.

Hard as this fact is, it needs a bit of background information. In the fall of 1916, a group of some twenty artists and a few art patrons gathered several times in the Upper West Side apartment of Walter and Louise Arensberg, an eccentric couple who would become Duchamp's most faithful collectors and who, at the time, held an informal salon attended by the crème de la crème of New York's literary and artistic avant-garde. The purpose of the group's meetings was to devise a durable alternative to the juried exhibitions of the National Academy of Design. The group was bolstered by the success of the 1913 Armory Show and the experience of the artists gathered around Robert Henri in the Independents Group of 1910, who had momentarily succeeded in freeing themselves from the stifling strictures of the Academy. Resulting from their discussions, the Society of Independent Artists was incorporated on December 5, 1916, and endorsed by the Justice of the Supreme Court of the State of New York two days later. The motto of the Society was "No Jury, No Prizes," a strong rebuttal of academic authority and an equally strong plea for democracy and egalitarianism in art. An aggressive recruitment campaign was launched in January 1917, and it was so successful that on the evening when the Society's first exhibition opened for the VIPs, the Independents counted no less than 1,235 members.

On that very evening, April 9, a little magazine titled The Blind Man, No. 1, advertised as Independents' Number, was handdistributed at the opening. ${ }^{5}$ Its cover was adorned with a cartoon 
by Alfred Frueh representing a blind man guided through a painting exhibition by his dog and unaware of the framed nude on the wall thumbing her nose at him (Fig. 1.2). On the last page, a colophon mentioned: "Published by Henri Pierre Roché," a writer and journalist for Le Temps who had arrived from Paris at the end of October and shortly thereafter befriended Duchamp and the Arensbergs. In spite of the magazine's ironic title and cover design, its main feature, a long editorial signed by Roché, praised the Indeps (as they were familiarly called) at length without a hint of sarcasm. It rather pompously opened with these lines: "The Blind Man celebrates to-day the birth of the Independence of Art in America." The only two other contributors to The Blind Man's first number were the poetess Mina Loy and Beatrice Wood, a young actress, artist, and writer involved in a semi-chaste Jules et Jim-kind of relationship with Roché and Duchamp. ${ }^{6}$ A note at the bottom of the cover stated: "The second number of The Blind Man will appear as soon as YOU have sent sufficient material for it.”

Is it sheer coincidence that The Blind Man's second number appeared in May, after the closing of the exhibition? (Fig. 1.3) Of course not. Was its content the material sent by the YOU the first number addressed and solicited? With a few exceptions, no, but even the exceptions-the critic Frank Crowninshield, for example, or Gabrielle Buffet-Picabia-were art world insiders. The public at large was represented by a "mother" who sent a letter protesting that "People without refinement, cubists, futurists, are not artists," but the letter was a counterfeit due to Beatrice Wood. All contributors were members of a tightly knit community of avant-garde artists with, more or less, shared moral and aesthetic values and, perhaps more importantly, with common networks and an intersecting social life. ${ }^{7}$ There was no mention of a publisher's name this time, but above the title on the front cover the three letters P. B. T. cryptically alluded to the magazine's editors, $\mathrm{P}$ for Pierre (Roché), $\mathrm{B}$ for Beatrice (Wood), and $\mathrm{T}$ for Totor, diminutive of Victor-the nickname Roché, charmed by Duchamp's elegant command of even the most embarrassing social situations, had given his new friend in late January. Right beneath the title, the address, 33 West 67 th Street, New York, referred to the seat of the magazine's office, which happened to be the apartment of the Arensbergs. ${ }^{8}$ And beneath that address, a reproduction of Duchamp's 1914 Chocolate Grinder claimed the reader's attention, duly captioned "BROYEUSE DE CHOCOLAT" on the left and "Marcel Duchamp" on the right. A month earlier, an article in Everyweek entitled "Sometimes We Dread the Future" had disclosed that Duchamp, "the Whistler of 




\section{$\mathrm{P} \cdot \mathrm{B} \cdot \mathrm{T}$ \\ THE BLIND MAN}

33 WEST 67th STREET, NEW YORK

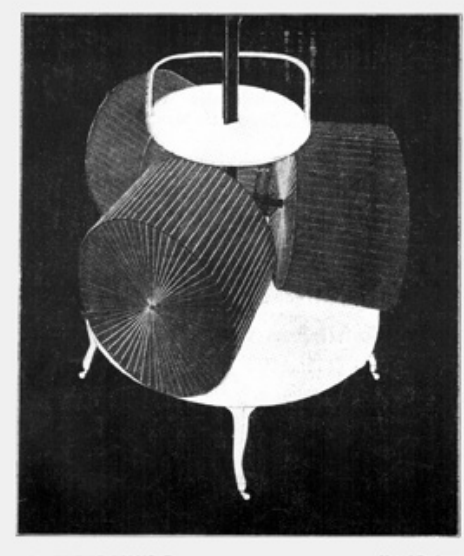

MAY, 1917

No. 2

Price 15 Cents

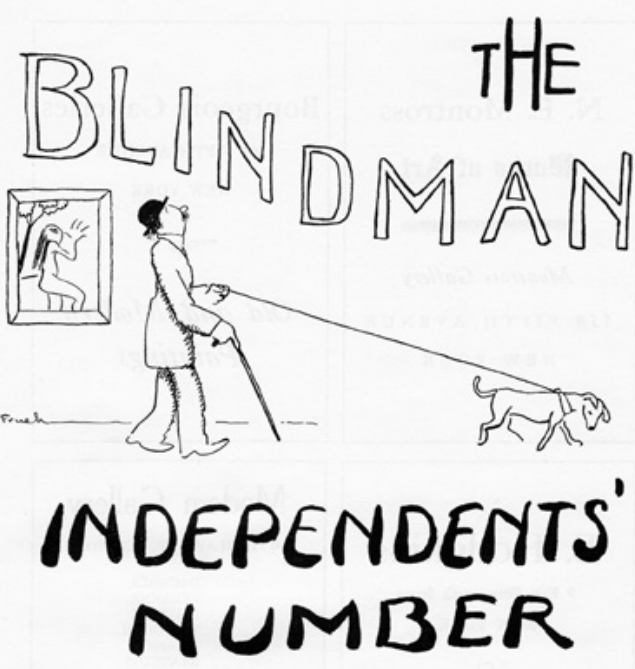

APRIL - $10^{\mathrm{W}}-1917$

No. 1 .

PRICE IOCTS

The second number of The Blind Man will appear as soon as YOU have sent sufficient material for it.

The Blind Man 38 West e7th Stsedth
Fig. 1.1

Henri-Pierre Roché (?), Marcel Duchamp's Studio, 1918. New York, Philadelphia Museum of Art, Alexina and Marcel Duchamp Papers. () 2009 Artists Rights Society (ARS), New York / ADAGP, Paris / Succession Marcel Duchamp.

Fig. 1.2

Cover of The Blind Man No.1, April 1917, facsimile edition. New York, The Ugly Duckling Presse, 2017.

Fig. 1.3

Cover of The Blind Man No.2, May 1917, facsimile edition. New York, The Ugly Duckling Presse, 2017. 




THE EXUHYT REFU⿴囗D BY THE INDEPENDENTS

\section{THE BLIND MAN}

\section{The Richard Mutt Case}

They say any artist paying six dollars may exhibit.

Now Mr. Mutt's fountain is not inmoral, that is absurd, no more than a bath tub is immeral. It is a fixture thet Mr. Richard Mutt sent in a you see every day in phumber' tbow windoses. fountain. Without discussion Wbether Mr. Mutt with his own hands this article disappeared and made the fountain or not has no importance. never was exbibited. What were the grounds for refusing disappeared under the new title and point of Mr. Muti's fountain:-

1. Some contended it was immonal, vulgar.

2. Others, it was plagiarism, a plain piece of plumbing.

As for plumbing, that is absurd. The only works of art America has given are her plumbing and her bridges.

\section{"Buddha of the Bathroom"}

I suppose monkeys hated to lose their ing thing about our human institution is tail. Necessary, useful and an ornament, that although a man marry he can nevet moilless existence (nion could not stretch to a be only a husband. Besides being a money. the biological beauty of our ly, do you see making device and the one man that one yet now that we are used to it, we get oo . woman can slecp with in legal purity withpretty well without them. But evolution woman's yery personification of her abis not pleasing to the monkey race: "there stract idea. Sin, while to his employees he do not love death change" and we monkeys is nothing but their "Boss," to his children like those philosophers whom Dante plased tainly something more complex in his Inferno with their heads set the But with objects and idess it is different Wrong way on their shoulders. Wc walk Recently we have had a chance to observe of his pretecin backivald, each with more their meticulous monogomy. of his predecessors pernonality than his The ideas that our ancesters When the jurors of The Society of In. dependent Artists fairly rushed to remove together let no man ancestors have joined the bit of sculpture called the Fowntain Dissociation des Idees, Remy de Gour- was irrevocably anociat, because the object mont, quietly analytic, shows how sacred is minds with a certain natural function of the marriage of idcas. At least one charm. secretive sort. Yet to any "innocent" eye
Fig. 1.4

Double page from The Blind Man No. 2, May 1917, facsimile edition. New York, The Ugly Duckling Presse, 2017. 
Cubism,” was preparing a bombshell for the Indeps' exhibition: the portrait of a chocolate grinder. ${ }^{9}$ Although Duchamp abstained-he didn't send anything to the Indeps under his name-he saw to it that The Blind Man No. 2 delivered the said portrait.

The pièce de résistance in The Blind Man No. 2 is undoubtedly the double page that divulges the Richard Mutt Case (Fig. 1.4). The left page exhibits a photo of a urinal, accompanied with a triple caption: "Fountain by R. Mutt," "Photograph by Alfred Stieglitz," and "THE EXHIBIT REFUSED BY THE INDEPENDENTS." Three times the word "by," three allusions to an agency. What kind of agency? It makes some sense to say that R. Mutt appears as the author of Fountain and a lot of sense to say that Stieglitz is the author of the photo, but it does not make much sense to say that the Independents are the authors of the fountain's refusal. One does not author a refusal the way one authors a work. Though the word "by" repeats itself identically, nothing forces us to characterize the implied agency as identical. The three captions deserve a closer look.

\section{FOUNTAIN BY R. MUTT}

On the page facing Stieglitz's photo, the editorial titled "The Richard Mutt Case” unequivocally states R. Mutt's agency with regard to Fountain in capital letters: "He CHOSE it." Choice is or is not a straightforward concept depending on whether or not we decide to ignore that Duchamp was hiding behind the pseudonym R. Mutt. One only needs to recall his 1968 response to Francis Robert's question, "How do you choose a readymade?""It chooses you, so to speak"-to fathom how complex the issue of choice in Duchamp's work can be. ${ }^{10}$ For the time being, let's put our hindsight knowledge in parentheses and try to read The Richard Mutt Case with the same ignorance of who was hiding behind R. Mutt as the 1917 readers of The Blind Man. "He CHOSE it" is prefaced with the following statement: "Whether Mr. Mutt with his own hands made the fountain or not has no importance." The editorial consistently speaks of "the fountain," lowercased and not italicized. "Fountain" is a common noun simply naming a genre of public monuments, as in this other passage: "Mr. Richard Mutt sent in a fountain.” If it were not for Stieglitz's photograph, we might think Mutt sent in an object in the same vein as Helen Farnsworth Mears's Fountain of Joy, reproduced in the catalogue, or Elizabeth Pendleton's Drinking Fountain for Birds, which we know was exhibited at the Independents thanks to Henry McBride's illustrated article in The Sun of April 8, 1917. 
The Richard Mutt Case editorial does not state that Mutt made the fountain into art, merely that "he placed it so that its useful significance disappeared under the new title and point of viewcreated a new thought for that object." However, in referring to the word "fountain" as "the new title," the editorial suggests that "Fountain" is a title and thus not simply the common noun of a genre of public sculpture. Moreover, it also suggests that the object in the photo already had a title before Mr. Mutt gave it a new one. Objects have a name but not a title, unless they are seen as works of art. To this oblique and ambiguous allusion to art, the last paragraph adds a direct and blunt one, emphasized by being printed in large, bold typeface: "As for plumbing, that is absurd. The only works of art America has given are her plumbing and her bridges.” Plumbing and bridges do not have titles the way works of art do, yet the editorial presents them as being evidently art, independently of Mr. Mutt's intentions and opinions. The innuendo that the fountain had been from the outset waiting for a new title, a new point of view, and a new thought to see its latent art status fully come into the open runs through the whole editorial and strikes a particularly odd note in the accusation of plagiarism, an accusation that makes sense only if the plagiarized object has an author, not simply a maker. The innuendo is even subtler in the next paragraph, which defends the urinal against the accusation of being immoral with these words: "It is a fixture that you see every day in plumbers' show windows." Not in public men's rooms, as you might expect, reading "every day," but rather in show windows, or in showrooms such as the spectacular outlet of the J. L. Mott Iron Works Company at 118, Fifth Avenue, where Mutt allegedly purchased the object. It is not usage that the editorial underlines, it is exhibition: precisely what Mutt's fountain has been denied.

The art historian who knows who was hiding behind R. Mutt and who surmises that the same individual steered the hand that wrote the unsigned editorial (usually attributed to Beatrice Wood) cannot fail to suspect that only a European, or at any rate a foreigner, could have written, "The only works of art America has given are her plumbing and her bridges.” But this is not so. As Kirk Varnedoe and his team have discovered:

The front page of the Trenton Potteries Company publication of May 1915 remarked: "Someone has said that, so far, the great contribution of America to Art is the pure white American bathroom."11 


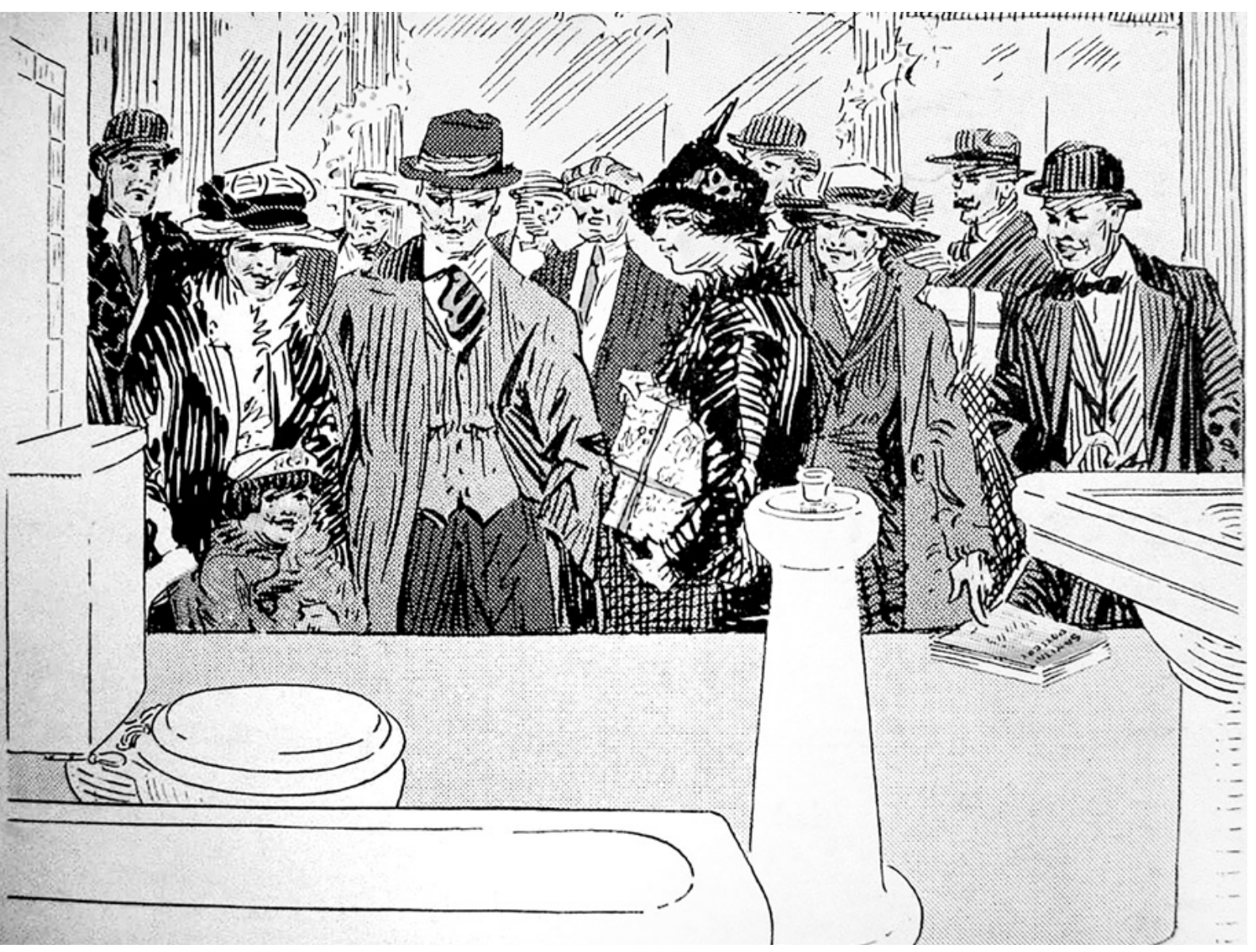

Fig. 1.5

Cartoon published in Sanitary Pottery, vol. 8, no. 8

(December 1916). 



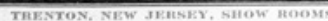

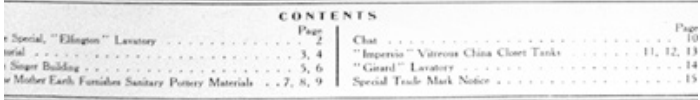

The Trenton

Potteries Company

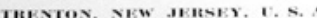



Fig. 1.6

Sanitary Pottery, vol. 1, no. 3 (June 1909), cover.

Fig. 1.7

Sanitary Pottery, vol. 7, no. 3 (July 1915), cover. 
The display of sanitary fixtures was moreover a developing, studied craft by this time. Trade journals admonished that "Artistic Display of Sanitary Plumbing Facilities is Promotive of Increased Sales," and the Mott company boasted that its showrooms were "artistic and beautiful." Booths at trade conventions were judged "from an artistic viewpoint" and prizes were awarded for presentation. Remarked one such review of a sanitary pottery show, flatly: "This display is a work of art." 12

As Varnedoe concludes: "Thinking about toilets as art was an already existing practice." 13 There is thus nothing farfetched in reading the Richard Mutt Case editorial as insinuating that the fountain in the photo was a work of art already, even before Mutt chose it. Images culled from professional publications of the time amply confirm that elevating bathroom implements to quasi-art status was common practice because it was a good commercial strategy. The Plumbers' Trade Journal of September 1, 1917, illustrated an article titled "Window Displays with 'Pulling' Power Create Sales" with a cartoon that showed a crowd admiring a washbasin in the vitrine of a plumbing store (Fig. 1.5). ${ }^{14}$ In June 1909, the journal Sanitary Pottery, issued by the Trenton Potteries Company, then in its first year, rather crudely adorned its cover with a photo of the Trenton showroom that had four or five urinals aligned on the wall amidst a row of toilet seats (Fig. 1.6).15 The editors subsequently developed more refined advertising tactics geared specifically at the middle class clientele, for whom owning a full porcelain bathroom was an enviable bourgeois luxury: they inserted in the December 1916 issue a drawing that showed, from inside the store's display, a crowd of well-to-do Christmas shoppers admiring the fully equipped bathroom on view (Fig. 1.7).16 And for the cover of the July 1915 issue of the magazine, they hired an artist who, in typical linear Art Nouveau style, represented two ladies of the world in awe before the bathroom trinity - tub, basin, and toileton view on an elevated plinth. ${ }^{17}$ "Bathroom trinity," by the way, is the expression Carl Van Vechten, one of the rare insiders in the R. Mutt affair, used when he wrote to Gertrude Stein: "Stieglitz is exhibiting the object at '291." 18 We shall soon examine whether the fountain was exhibited at "291" (Stieglitz's gallery). What is sure is that objects of its kind-perhaps not urinals but certainly toiletshad already been the topic of an exhibition in an art museum two years before the Independents' show. In a very well documented 
essay on ceramic sanitary ware of the period, Ezra Shades tells us that in April 1915, John Cotton Dana, Director of the Newark Museum Association, curated an exhibition titled New Jersey Clay Products that included "vitreous china" water closets and earned the following comment from a critic:

To see what is called "sanitary ware" and drain pipes and the kind of tableware in use in "quick lunch" restaurants and building bricks solemnly displayed in the guise of art, certainly would disturb our museum pundits. Yet over in Newark there is a director of a library and art museum who has had the courage to do just such a thing as this. ${ }^{19}$

In 1915, water closets were already deemed worthy of an exhibition in an art museum, if not in the name of art and as works having their place in the fine arts, then in the name of good design or what in Germany was called Kunstgewerbe. The art historian who knows who was hiding behind R. Mutt but doesn't rely on knowledge of post1917 Duchamp to read The Blind Man's editorial might remember that in the summer of 1912 Duchamp was in Munich and that he most probably visited the Bayerische Gewerbeschau, a gigantic and spectacular exhibition of semi-industrial, semi-artisanal wares displayed for their Qualität. ${ }^{20}$ The same art historian might also note the discrepancy between the workmanship and the handmade quality of the sanitary pottery, as stressed by the professional publications of the times, and the tenets of machine aesthetics stressed by the reception history of the readymades. The chances are high that Richard Mutt chose a particular model of urinal with the same discriminating care for good design-or is it artistic quality?-as the organizers of the Gewerbeschau.

Duchamp scholars are not in agreement as to what particular model Mutt chose. Camfield opts for either the 1902 Heavy Vitroadamant Urinal 839-Y or the 1908 Panama model, both sold by the J. L. Mott Iron Works, while Varnedoe and Glyn Thompson argue, most convincingly, for the flat-back lipped Bedfordshire Urinal offered either by the A.Y. MacDonald Company (Varnedoe) or by the Trenton Potteries (Thompson). ${ }^{21}$ More recently, Paul Franklin uncovered a fourth possible model, the standard porcelain flatback lipped urinal manufactured by J. L. Mott in the late nineteenth century. ${ }^{22}$ Does all of this matter? For the scholars who take the urinal to be a "gesture" or a "concept," the search for the right model is nothing but hair-splitting aestheticism. ${ }^{23}$ But to see the urinal as a "gesture" or a "concept" is to project onto the year 1917 the biases 
typical of the reception of Duchamp's readymades in the '60s and '70s. No reader learning in 1917 that R. Mutt "created a new thought for that object" would have concluded that the object in question had been reduced to a thought. Fountain was not conceptual art avant la lettre: aesthetic considerations entered R. Mutt's choice. It remains to be seen what considerations and for what purpose.

\section{PHOTOGRAPH BY ALFRED STIEGLITZ}

Stieglitz's agency with regard to the fountain is quadruple: he saw it, he aestheticized it, he made it into art, and he photographed itin that order (Fig. 1.8). The question of who beside Duchamp saw the urinal with his or her own eyes is still open, but the number narrows down to his accomplices, Henri-Pierre Roché, Beatrice Wood, Walter Arensberg, Louise Norton, and perhaps John Covert, Joseph Stella, and Carl Van Vechten on the one hand, and the directors of the Society of Independent Artists convened to an emergency meeting to decide on the fountain's fate on the other. There were twenty founding members to the Society, all called directors but, according to Camfield, only "a group of about ten was gathered to decide the issue," 24 among whom Arensberg, Covert, Rockwell Kent, George Bellows, Walter Pach, and William Glackens are the only ones we are almost certain attended the meeting. The public never got to see the urinal, nor did the journalists, who otherwise would have called the litigious object by its name rather than coyly citing "a bathroom fixture" or "a familiar article of bathroom furniture." ${ }^{25}$ And then there is Stieglitz. He saw the fountain and had to absorb the shock of discovering what kind of object it was. According to Beatrice Wood:

He was greatly amused, but also felt it was important to fight bigotry in America. He took great pains with the lighting and did it with such skill that a shadow fell across the urinal suggesting a veil. The piece was renamed: "Madonna of the Bathroom." 26

I am not so sure that Stieglitz was amused, at least not initially. Wood wrote this with considerable hindsight and probably remembers Stieglitz as relishing the idea of fighting bigotry in America and punishing the Indeps for their act of censorship after he had taken "great pains with the lighting" and succeeded in turning a urinal into a Madonna. ${ }^{27}$ Stieglitz decided to photograph the fountain, but not without first making it into a piece of sculpture whose gleaming surface and elegant curves could be appreciated aesthetically. He bathed the object in soft light and propped it against the 


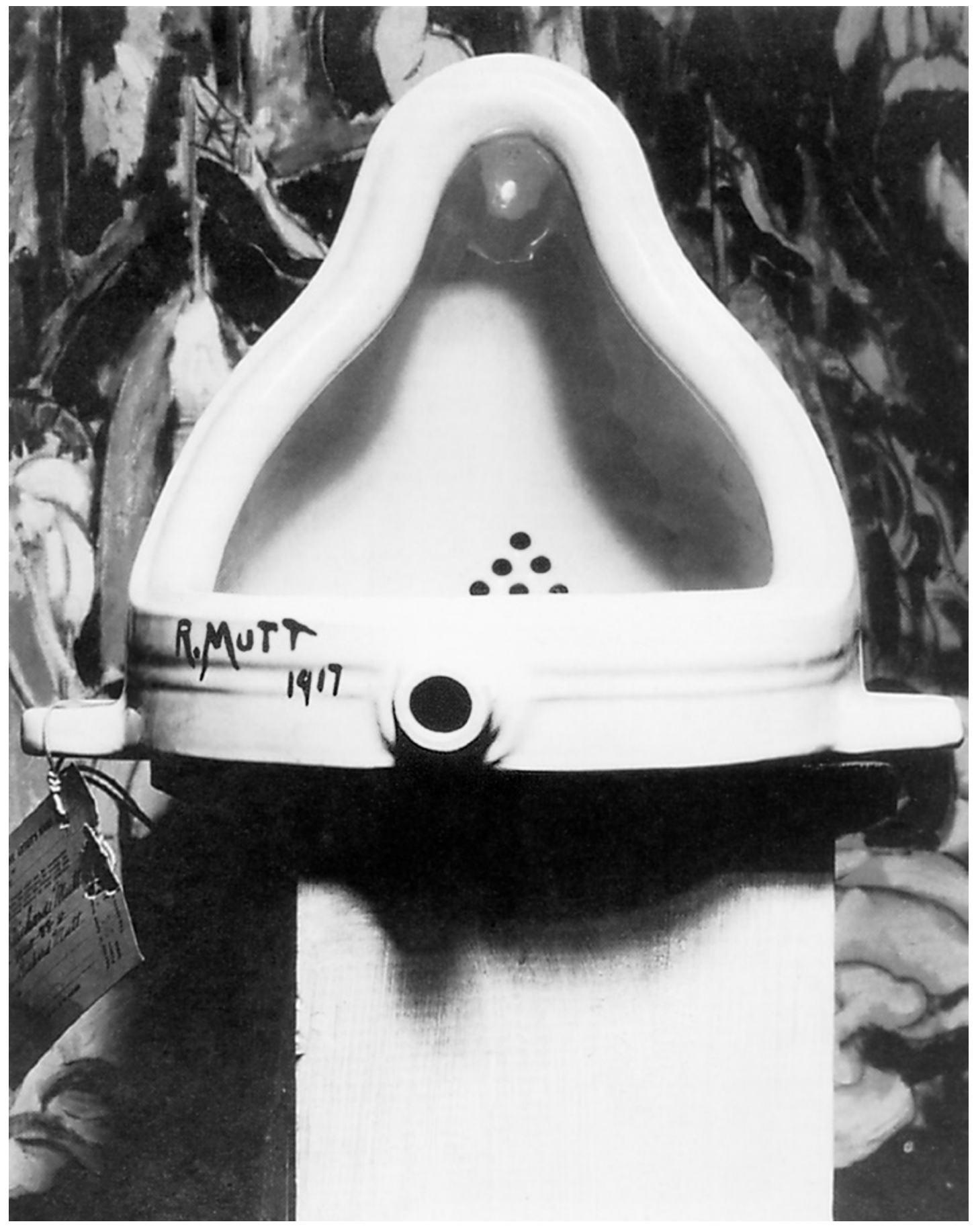

Fig. 1.8

Alfred Stieglitz, Photo of Fountain, 1917, $10.8 \times 17.9 \mathrm{~cm}$. Philadelphia Museum

of Art, The Louise and Walter Arensberg Collection, 1950. @ Artists Rights Society (ARS), New York / ADAGP, Paris / Succession Marcel Duchamp. 
background of a Marsden Hartley painting that contained ogival forms echoing the urinal's contours, something that is not readily observable in the photograph. As Michael Taylor perspicaciously noted, "this relationship would only have been seen by those present when the photograph was taken," a revealing insight into Stieglitz's mindset. ${ }^{28}$ Stieglitz could only fathom the Fountain if it was art, so he did everything to make it art to his own eyes. Then he photographed it, in protest against the Independents' betrayal of their democratic principles-a cause he took to heart. Indeed, in addition to making sure the incident was recorded, Stieglitz contributed a letter to The Blind Man, dated April 13, where he maintained that in the future all entries to the Independents should be anonymous, so that "each bit of work would stand on its own merits";29 and on the 19th he wrote to Henry McBride, the Sun's critic: "I wonder whether you could manage to drop in at 291 Friday some time. I have, at the request of Roché, Covert, Miss Wood, Duchamp \& Co., photographed the rejected Fountain. You may find the photograph of some use. It will amuse you to see it. The Fountain is here too." 30

On public view, as Carl Van Vechten thought? Certainly not. Stieglitz was not only a photographer of great renown; he was also the director of a major art gallery, located at 291, Fifth Avenue, not far from the J. L. Mott showroom. There he had shown Rodin's watercolors and Matisse's drawings and was representing a stable of American avant-garde artists, among whom were Hartley and the "Big Three," as he called his favorites: John Marin, Arthur Dove, and his soon-to-be wife, Georgia O'Keeffe. As much as he sought to aestheticize the urinal and elevate it to art status, he also wanted to make clear that he did not endorse R. Mutt to the point of showing his fountain at "291." He had not much respect for the clique of "Roché, Covert, Miss Wood, Duchamp \& Co.” and he thought at the time that Duchamp was a charlatan. Perhaps the fountain was art, but not art good enough to be exhibited in his gallery. When Carl Van Vechten wrote to Gertrude Stein, "Stieglitz is exhibiting the object at '291,"' he was running ahead of himself: only the happy few were invited to witness what the mysterious bathroom fixture the Independents had censored looked like.

There is a detail in Stieglitz's exquisitely crafted photograph that is strangely at odds with his aestheticizing efforts and his careful mise-en-scène: the urinal does not sit centered on its base. On second view this casualness seems so contrived that it makes the mise-en-scène appear even more deliberate. With it, Stieglitz seems to be saying: "The urinal may sit like a Buddha on a pedestal, 


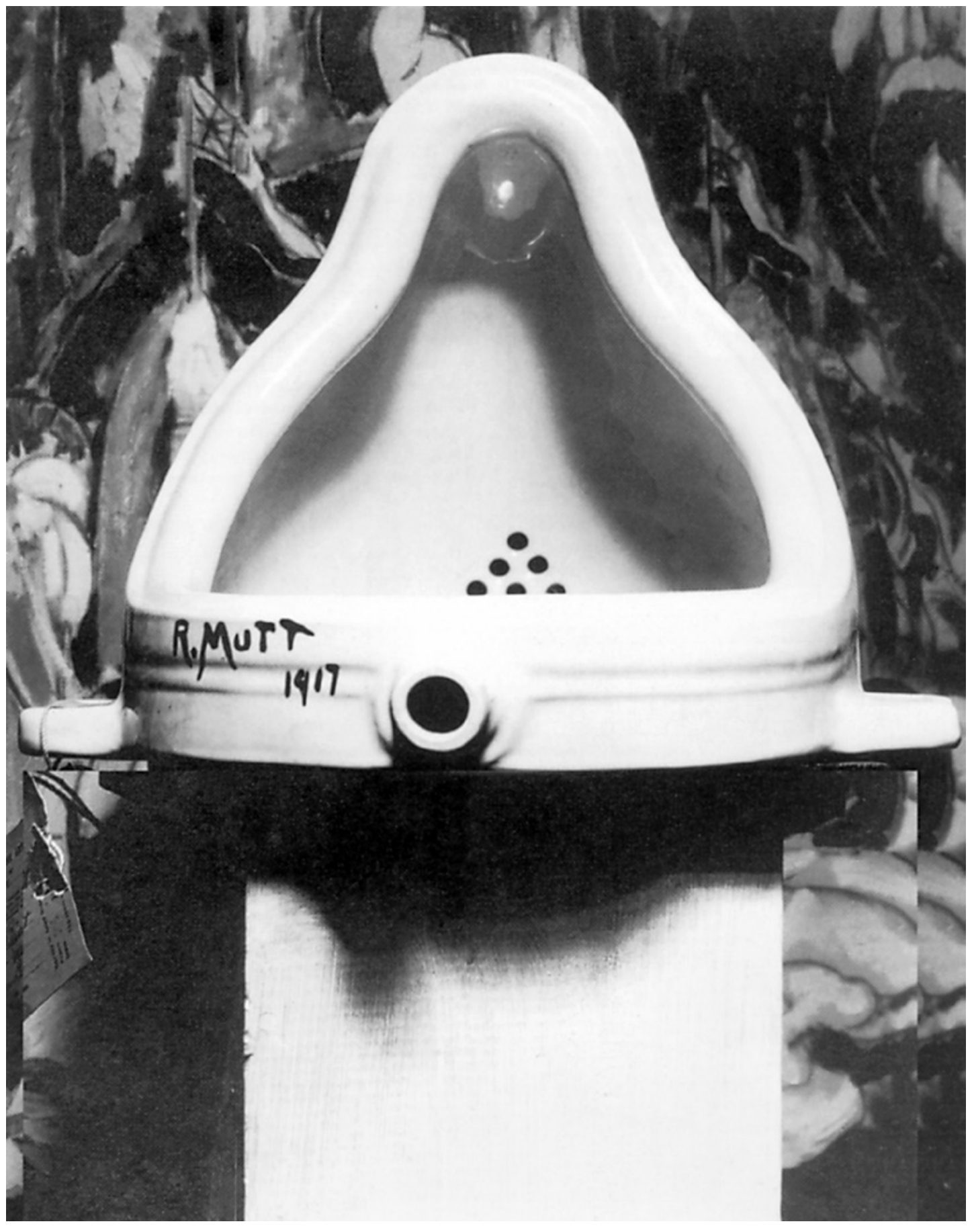

Fig. 1.9

Doctored version of Alfred Stieglitz, Photo of Fountain, 1917. @ Artists

Rights Society (ARS), New York / ADAGP, Paris / Succession Marcel Duchamp. 
but it landed there provisionally, for the mere purpose of being photographed as Exhibit A in my protest against the Independents, and not in order to be exhibited as a valued work of art.” And on third view, when you compare Stieglitz's photo with a doctored version that centers the urinal on its plinth, something else emerges: the original version of the photo gives the urinal plus base an elegant contrapposto that makes it far better, aesthetically, than the doctored version (Fig. 1.9). Better, that is, as a photo; it does not make the urinal look better. In the end, Stieglitz must have been satisfied that the fountain was art because the photo was a work of art he could be proud of.

\section{THE EXHIBIT REFUSED BY THE INDEPENDENTS}

What was the Independents' agency with regard to the fountain? They refused it, they censored it, and they made it into anti-art. Among the directors summoned to an emergency meeting on the morning of April 9, the day of the vernissage preceding the public opening, only Walter Pach, Covert, and Arensberg defended Richard Mutt's right to exhibit, on the grounds that he had paid his membership fee. Duchamp, who was a founding member and who, ironically, had been named head of the hanging committee a few days before, conveniently abstained from attending the meeting. Reminded of the cartoon strip characters Mutt and Jeff, George Bellows deemed the fountain a joke while William Glackens, president of the Society, called it the product of "suppressed adolescence," judging it to be indecent and certainly not a work of art. ${ }^{31}$ Whatever the invectives exchanged and the arguments adduced, Richard Mutt's fountain was rejected. There are several versions of the story depending on who tells it: the fountain has been surreptitiously stolen (Katherine Dreier); smashed by William Glackens (Charles Prendergast according to Glackens's son, Ira, who may have confused the urinal with a "chamber pot, tastefully decorated" he heard Prendergast mention ${ }^{32}$ ); hidden behind a partition and retrieved by Duchamp after the show ended (Duchamp to Pierre Cabanne, corroborated by Theresa Bernstein, an artist "who attended the exhibition and recalled having seen the urinal 'on a staircase landing, behind a curtain'”33); exhibited by Stieglitz at "291" (Van Vechten); or bought by Arensberg who, flanked by Duchamp and Man Ray, carried it out of the exhibition room as if it were a marble Aphrodite (Rudi Blesh, Arturo Schwarz). ${ }^{34}$ The least far-fetched of the various stories narrating the fate of Fountain is the one told by Rockwell Kent in his autobiography, It's Me, OLord, in which he writes that after a heated discussion, "the committee's 
saner members" won the case and found a way to refuse Fountain on the basis of a technicality: "the entry card did not identify the urinal's creator." 35 But even this version is dubious, as it seems to have been dictated by Kent's a posteriori knowledge of Richard Mutt's true identity. In Stieglitz's photo, the entry card attached to the urinal is partly visible and, so far as we can tell, looks properly filled in-provided, of course, we read the artist's name candidly.

The only assured fact amidst these stories is that the urinal was at "291" most or all of the time between April 13, when Beatrice Wood wrote in her diary, "See Stieglitz about 'Fountain," and April 19, when Stieglitz invited McBride to come and see it. ${ }^{36}$ What happened to the fountain next is one of those mysteries of art history. "Nobody has ever found out what became of the original. The best guess is that it stayed at '291' after Stieglitz photographed it," writes Calvin Tomkins, Duchamp's most thorough biographer. ${ }^{37}$ But if we trust the Ephemerides, Roché photographed it in Duchamp's studio on June 3rd, 1918, more than a year after the affair. Next, Duchamp departed for Buenos Aires in August, and we definitively lose track of the infamous urinal. The only proofs that it ever existed are Rochés and Stieglitz's photos, and the only vehicle that was to carry its existence into art history books was the cropped version published in The Blind Man.

Unlike the jury's refusal of Manet's Le Déjeuner surl'herbe at the 1863 Salon, the refusal of the fountain by the board of directors of the Society of Independent Artists was a clear-cut act of censorship, perpetrated in blatant violation of the Society's principles. The Foreword to the catalogue of the Society's first exhibition stated:

The SOCIETY OF INDEPENDENT ARTISTS has been incorporated under the laws of New York for the purpose of holding exhibitions in which all artists may participate independently of the decisions of juries. [...] The great need, then, is for an exhibition, to be held a given period each year, where artists of all schools can exhibit together-certain that whatever they send will be hung and that all will have an equal opportunity. ${ }^{38}$

"Exhibitions in which all artists may participate..." "Artists of all schools..." "Certain that whatever they send will be hung..." These promises of all-inclusiveness and certainty were exactly what Richard Mutt proceeded to test. The Society's very existence was founded on the guarantee given to all members of the Society that their entry to the exhibition would be shown, and thus treated as 
art, without any judgment as to its quality. Article II, section 3 of the Society's bylaws stated:

Any artist, whether a citizen of the United States or of any foreign country, may become a member of the Society upon filing an application therefor, paying the initiation fee and the annual dues of a member, and exhibiting at the exhibition in the year that he joins. ${ }^{39}$

Sections 4 and 5 specified that the initiation fee would be one dollar and the annual dues five dollars. The inevitable conclusion was expressed in one journalist's comment with the appropriate irony:

Step up, ladies and gentlemen! Pay six dollars and be an artistan independent artist! Cheap, isn't it? Yet that is all it costs. [...] You and I, even if we've never wielded a brush, squeezed paint from a tube, spoiled good paint with crayon, or worked with a modeling tool, can buy six dollars worth of wall or floor space at the Grand Central Palace. 40

So that when the editorial's first sentence reads, "They say any artist paying six dollars may exhibit," what this unwittingly means is: "anyone paying six dollars may exhibit." It seems that, with the exception of Arensberg, who was in the know from the outset and gleefully played the game, the founding members had not fathomed that it followed straight from their "No Jury, No Prizes" motto that all rules of art making had been abolished by decree: if anyone with six dollars to spend on a membership card to the Indeps was an artist, and if artists of all schools could be certain that whatever they sent would be hung, then the truth was that, at the Society of Independent Artists, anything whatsoever could be art. The founding members should have been ready for that, but they were not. Richard Mutt's entry suddenly woke them up to that truth. Should we blame them for blaming Mutt for the waking call? They were only the firsts in the long list of people who would shoot-or hail-the messenger. But they got the message all right: they immediately understood that Mutt had taken advantage of something they had not thought out in all its consequences. And for that very reason they knew Mutt had set a trap for them, intentionally.

This is what I mean when I say they made the fountain into anti-art. They, not he. For anti-art is in the eye of the beholder. We should never assume that anti-art is anti-all art, even at the Cabaret 
Voltaire-witness Hugo Ball's cathectic belief in the redemptive value of Dada poetry. ${ }^{41}$ We should assume, rather, that it is what an artist does who is opposed to this or that kind, or brand, or style, or conception, or avatar of art, and who makes a statement of his particular opposition. It is the particularity of the attack that accounts for the "anti" in anti-art. And it is therefore the particular party that feels attacked that lends the artist the will to attack it, whether or not the will is there. The directors of the Indeps who gathered to decide on the fate of Mutt's fountain imputed the prankster the intention to ridicule the conception of art they stood for. Mutt, they thought, must be an anarchist set out to make fun of the bourgeois liberalism the Independents professed when they wrote, "every school is represented at this salon, from the most conservative to the most radical." 42 Or he must be an arch-conservative who has viciously reached for the scandalous and the far-out in order to discredit the Independents' democratic principles: perhaps an adept of Royal Cortissoz, the reactionary critic for the New York Tribune who saluted the Indeps with an article significantly titled "The Danger of Mixing Democracy and Art, What the Society of Independent Artists Has Done to Discredit the Old Idea of an American Salon.” In that article Cortissoz wrote:

Not art, but democracy is in charge. It is a comfortable situation, no doubt. All men are created equal. Then one artist, of course, is as good as another. Away with juries! They smack of sifting processes, of standards of taste, of discipline. Under their ministration the dabster frequently has to make way for the artist. That is despotism and tends to the triumph of convention. There is a lynching picture in this exhibition. The gentleman aloft might be the last juryman, the last obstacle between the independent artist and undying renown. [...] But it is unlikely that the juryman will stay dead. At the Academy and elsewhere he will, on the contrary, continue to exercise his useful, indispensable functions, and hanging committees will likewise endure, to do their share in making exhibitions artistic. ${ }^{43}$

History did not vindicate Cortissoz. The juryman stayed dead; academies wilted; a new art world came into being. But the habit of imputing Duchamp alias Mutt the intention to mock and destroy not only remained; it was rewarded by Fountain's reception history, which on the whole read the urinal as the epitome of anti-art, even of anti-all art-a counterintuitive thesis that could only come to the mind of ideologically biased theorists who fantasize that avant-garde 
artists are set to attack the whole of art as an institution. ${ }^{44}$ Was the institution of art-and if yes what institution of art-the target of Mutt's attack? Was anti-all art indeed Mutt's intent? Mutt had no intent-no intention of his own. Richard Mutt was a creature of Marcel Duchamp. This, of course, begs the question of Duchamp's intention when he created him. We can no longer, at this point, read The Blind Man's editorial as if we ignored who was lurking behind Mutt. But we should be careful not to project onto Duchamp in 1917 what we think we know from Fountain's reception history or from the statements he made much later, such as his various diatribes against "retinal" art dating from the '60s.

So let's ask, as if we didn't know the answer, whose agency it was that produced (in both senses of the word) The Blind Man and its illustrated editorial? The culprit's name appears twice in the magazine: once innocently on the cover, as the author of Broyeuse de chocolat, which the cover reproduces; and a second time less innocently, in the last sentence of an article on the painter Louis Eilshemius, signed Mina Loy: "Anyhow, Duchamp meditating the levelling of all values, witnesses the elimination of Sophistication." 45 Whatever Mina Loy may have meant with "the elimination of Sophistication," she cast Duchamp as a witness, someone who testifies to a reality he has seen with his own eyes, or understood with his own brain, and makes that reality public. She didn't tell us what Duchamp's intention was in doing so. We have no other choice but distilling it from his agency with respect to the three agencies the repetition of the word "by" in the captions to the photo conjures up. Let's revisit them.

\section{AGENCY, INTENTION, MOTIVATION}

Fountain by R. Mutt. Duchamp's agency vis-à-vis Richard Mutt is clear: he created him and he chose a name for him. His intentions in creating and naming Mutt are almost as clear: he needed a pseudonym behind which to hide because he wanted the Independents to ignore who the sender of the urinal was. But his choice of Mutt is duplicitous, in that respect. "Mutt" deliberately sounds like a pseudonym and therefore raises suspicion and invites speculation. It is a transparent allusion to the cartoon characters Mutt and Jeff, which in 1917 no New Yorker would have failed to recognize. With her characteristic lack of humor, Duchamp's friend and future owner of the Large Glass, Katherine Dreier (who was among the founders of the Society), complained in a letter to William Glackens dated April 26: 
I told Covert and Arensberg that in my judgment Richard Mutt caused the greatest confusion by signing a name which is known to the whole newspaper world as a popular joker. "Mutt and Jeff" are too famous not to make people suspect, if their name is used, that the matter may be a joke. ${ }^{46}$

Dreier was so eager to believe that Mutt had been serious and sincere that only in horror did she entertain the possibility that he might have been a practical joker. Was that the point of Duchamp's choice of the name "Mutt"? Did he want the sender of the fountain to appear as a practical joker? Probably, but then only as a coverup for the seriousness with which "Mutt" alluded to Mott-the J. L. Mott Iron Works, possibly the real manufacturer of the urinal and at any rate the exhibitor of similar models in its Fifth Avenue showroom. The difference between the two names is not even a letter: you change an "o" into a " $u$ " the way you crack open a soft-boiled egg: by chopping off the top. That subtle amputation should be enough to bring about sophisticated reflections on the semi-artisanal making of urinals and their display as quasiart in plumbers' show windows. The various innuendos of The Blind Man's editorial invite such reflections. The fact that they came to nobody's mind until very recently shows how massively the reception history of Fountain in terms of anti-art, machine aesthetics, contempt for the hand, dehumanization, commodity fetishism and/or its critique, and Fountain's later redemption as proto-conceptual art, have obliterated Duchamp's true intentions, as distilled from his agency with respect to the triple "by" in the captions to Stieglitz's photo.

Photograph by Alfred Stieglitz (Fig. 1.8). What, now, was Duchamp's intention when he decided that Stieglitz, not Man Ray or Henri-Pierre Roché or an anonymous photographer, should photograph the fountain? He knew that Stieglitz was not just a famous photographer but also an art dealer commandeering the ne plus ultra of avant-garde art in New York. He knew that Fountain being at "291," even for a few days, even visible only to a happy few, would be obtaining for the controversial urinal the sanction of art history in advance. Duchamp manipulated Stieglitz, no doubt. How? This is where the aesthetic criteria with which he chose a particular model of a urinal-the gleaming white surface, the Hans Arp- or Brancusi-like curves, the potential formal evocation of a Buddha or a Madonna-set in. They were a trap set for Stieglitz, and he fell into it. He wouldn't have aestheticized the fountain to the point of elevating it to art status if he hadn't felt that the 
object had aesthetic potential in spite of its plebeian origin and vulgar connotations.

THE EXHIBIT REFUSED BY THE INDEPENDENTS. Finally, what was Duchamp's agency vis-à-vis the Independents? He set a trap for them, too, and they, too, fell into it. And what was Duchamp's intention in setting that trap? Did he want to mock or sabotage the Indeps' liberation struggle against the National Academy? Did he seek to delegitimize them? Not at all. Otherwise he wouldn't have waited until the exhibition was over to reveal that a controversy involving a urinal had shaken the Society's board of directors on the day of the opening. Otherwise he wouldn't have seen to it that nobody except his immediate accomplices would be informed of R. Mutt's identity, even to the point of hiding it from his sister Suzanne, to whom he wrote on April 11: "One of my female friends, under a male pseudonym, Richard Mutt, sent in a porcelain urinal as a sculpture." 47 Otherwise he wouldn't have made sure that the nature of the "bathroom fixture" sent in by R. Mutt was not leaked to the press.

On May 6, the day of the show's closing, the New York Tribune published a cartoon that depicted all sorts of artistic aberrations supposedly shown at the Indeps: abstract sculptures lassoed by art movers, a grandmother's quilt being returned to her because nobody would buy it, or a painting so aggressive it foot-kicked a spectator in the face, not to mention the inevitable child's stick figure drawing. Not a trace of a urinal! One easily imagines the field day the cartoonist would have had if only he had known. Even more interesting: perhaps he did know. Indeed, the cartoon was due to Louis M. Glackens, the brother of William, none less than the Society's president. Either William never told his brother of the repressed scandal or he requested his silence, in both cases out of fear that the scandal would break out. It is that fear that Duchamp perversely stoked but also respected, in the most gentlemanly manner imaginable, when he decided to reveal the Richard Mutt Case only after the Independents' show had closed.

If Duchamp did not seek to delegitimize the Indeps or mock and sabotage their liberation from the National Academy, what then did he want? He wanted the board of directors of the Independents to refuse and censor the fountain. It was that goal that commanded the choice of a urinal-it didn't matter what particular model of a urinal, this time, nor even that the object was a urinal, as long as its choice made sure the directors would be afraid that if the object were exhibited it would discredit the whole Society, make them appear as fools, and kill their project in the cradle. They could not, 
would not allow that to happen. The gambit was risky. What if the directors had already been accustomed to the public display of porcelain toilets in an art exhibition and had decided to go along? What if they had remembered that Duchamp had exhibited two readymades at the Bourgeois Galleries a year before and guessed who was lurking behind R. Mutt?48 What if they had been more embarrassed at the prospect of antagonizing a founding member as prominent as Duchamp than of exhibiting a urinal? Duchamp's gambit was a wager, and he won. The Independents censored the fountain and betrayed their principles. From which we gather that to make them betray their principles must have been Duchamp's ultimate intention.

It has been a little while now that we are treading the delicate territory where hard facts yield to speculation about agency, intentions, and motives, and where the risk is great of indulging in what is known as "the intentional fallacy." 49 Intentions and motives cannot be deduced from the facts we possess regarding agency; they must be divined from them, under the presumption of some coherence, whereby motives explain intentions and intentions account for actions. The act is one thing, the intent behind the act another, and the motive behind the intent still another. Duchamp's acts in the R. Mutt affair-creating Mutt, manipulating Stieglitz, setting a trap for the Indeps-have complex intentions that seem to converge on the goal of making the Indeps betray their principles. I do not second-guess the motivation behind these intentions pretending to creep into Duchamp's brain. As we shall see, I base myself on further facts: the answer most likely to make sense of the whole chain of motive, intention, and agency is talionism.

\section{TALIONISM}

Anote in Duchamp's White Box states: "Du Scribismeilluminatoresque dans la peinture (Plastique pour plastique talionisme)." 50 In Cleve Gray's translation from Salt Seller: "A kind of illuminatistic Scribism in painting (A plastic for plastic retaliation)." 51 And in the translation resulting from the joint efforts of Richard Hamilton, Jackie Matisse, and Ecke Bonk: "On illuminatoresque Scribism in painting (Plastic form for plastic form talionism)." 52 "Retaliation" adequately conveys the meaning of the Biblical lex talionis, "an eye for an eye." 53 But the literal "talionism" is the better translation, for it conveys the sense that revenge has been promoted to the rank of artistic "ism," like impressionism or cubism, or indeed, in Duchamp's idiolect, scribism, ironism, oculism, and pictorial nominalism, not to mention eroticism. ${ }^{54}$ An eye for an eye, a tooth for a tooth, an "ism" 
for an "ism." Where and when did Duchamp find the impetus to make revenge an artistic "ism"? What artistic "ism" was the target of his vengeance? What was the particularity of the attack accounting for the "anti" in anti-art, if indeed Fountain was anti-art?

The year is 1912, the place Paris. In January, Duchamp, who was not even twenty-five, finished painting the second version of Nude Descending a Staircase (Fig. 4.1) in the cubist idiom he had been teaching himself since the summer. It is not clear whether he realized that the painting, which, like Sad Young Man on a Train from the previous month, depicted movement, could be seen as more futurist than cubist. At the time he had not seen a futurist picture yet, and it was not until February that the Gallery BernheimJeune put up a show of futurist paintings. In March young Marcel, who was still very much looking up to his older brothers, the painter Jacques Villon and the sculptor Raymond DuchampVillon, both cubists, was eagerly preparing to exhibit his Nude Descending a Staircase (No. 2) in the cubist room of the Salon des Indépendants. The painting was to earn him his official induction into the most talked about avant-garde of the time. Cubism had made a spectacular entry at the Indépendants the previous year, when a few cubist artists led by Albert Gleizes and Jean Metzinger convinced the organizers to let them exhibit as a group, in their own room, with their own hanging committee. The same strategy was successfully repeated at the 1912 Salon, where Gleizes and Metzinger, together with Henri Le Fauconnier, Fernand Léger and Alexander Archipenko, formed the hanging committee of the cubist room.

In compliance with the motto, Ni jury ni récompense (the same motto as the New York Indeps' No Jury No prizes - more about that identity soon), the committee was supposed to confine itself to installation decisions. Yet when Duchamp arrived with the Nude Descending a Staircase, Gleizes and Metzinger, who were about to publish a very dogmatic treatise/manifesto titled $\mathrm{Du}$ Cubisme, 55 were taken aback by the painting's unorthodox facture and title, which they deemed more futurist than cubist. They delegated Marcel's brothers to tell him to remove his painting from the show. Jacques and Raymond tried a mediation by asking Marcel to change the title, but Marcel refused and the guardians of orthodox Cubism prevailed: the painting was censored. As Calvin Tomkins wrote in his biography of Duchamp:

He said nothing to his brothers, who so evidently had failed to take his side in the dispute. No argument, but no compromise 
either; he would not change the title. Although Duchamp suppressed whatever emotions were involved, the effects of the rebuff were deep and permanent. 56

Duchamp withdrew the painting, mortified-so mortified that he stopped attending the meetings of the Puteaux group at his brothers' house or at Gleizes' studio in Courbevoie and a few months later took exile in Munich, where he would remain until the fall. Even though the Nude was rehabilitated at the Salon de la Section d'Or in October and enjoyed a tremendous succès de scandale at the Armory Show in February 1913, he would never forget and never forgive. "It was a real turning point in my life," he said to Tomkins. "I saw that I would never be much interested in groups after that." 57

This interesting remark may explain Duchamp's subsequent lukewarm involvement in surrealism, or even in New York Dada. But it flatly contradicts his very active involvement in the creation of the Society of Independent Artists. The group that gathered at the Arensbergs' apartment to plot a durable alternative to the juried exhibitions of the National Academy was enthralled with his participation. Nothing could have been more propitious to their project than the endorsement of the sulphurous yet celebrated author of the Nude Descending a Staircase. John Sloan, George Bellows, Maurice Prendergast and William Glackens had brought to the table the already stale prestige of the Ash Can School, dragging along Charles Prendergast and Rockwell Kent; John Marin had the privilege of being Stieglitz's favorite, and John Covert that of being Arensberg's cousin; both had a modest fame as cubists, as had Joseph Stella for being the only American futurist. It is not Walter Pach's mediocre reputation as a painter but rather his undisputed role as the great mediator in the organization of the Armory Show that predisposed him to play an equally prominent role in the launching of the Indeps. Only Francis Picabia, Man Ray and, to a certain extent, Morton Schamberg were in Duchamp's league. But Picabia had left for Barcelona in June and Jean Crotti, another French expat in Arensberg's circle briefly involved in the discussions, had returned to Paris a little later. The only Europeans present when the Society of Independent Artists was incorporated were Duchamp and Gleizes.

Imagine this motley assembly-to which we should add the stern Katherine Dreier-meeting and scheming in the Arensbergs' apartment. Who among them could possibly have suggested to model their project of an artists' society on the French Société des Artistes Indépendants? The Ash Can School alumni might have 
had something like Robert Henri's Independents Group from 1910 in mind, and Dreier might have proposed a variety of German Kunstvereine as viable models. But only a Frenchman or someone familiar with the French art institutions could have thought of the Indépendants. That leaves us with Duchamp, Gleizes, and Pach, who had lived in Paris on and off since 1908, was friends with all three Duchamp brothers, and had invited Marcel to show four paintings, including the Nude, at the Armory Show.

After having pondered over the available facts and testimonies, this is what I speculate happened at one of the meetings in the Arensbergs' apartment: Walter Pach mentioned the Indépendants first; Gleizes enthusiastically seconded him; and Duchamp nodded in approval. Pach might have preferred the Section d'Or but its Salon, which deeply impressed him in October 1912, didn't have the stability of an ongoing organization. The Indépendants, created in 1884 around Seurat, had impressive credentials: they had over a thousand members; their history went back more than thirty years; their Salon was as respectable as the three other Salons held annually in Paris; and their statutes could be readily adopted-and adapted. Gleizes, whom Tomkins portrays as "a born moralist" who "propounded the gospel of his 'reasonable' Cubism to anyone who would listen, undeterred by ironical looks and comments from Picabia and Duchamp," 58 seized Pach's proposal as an occasion to pontificate about cubism's groundbreaking presence at the Indépendants, and rhapsodized that importing their model would provide America with the ideal venue for serious vanguard art. And Duchamp chuckled silently, listening to Gleizes. He had suddenly realized that he held his opportunity to set the record straight.

Had Gleizes not been present at the meetings of the Indeps' founders, the R. Mutt affair might never have happened and the history of modern art would be quite different. It is my contention that Duchamp's talionism was hatched at one of these meetings. The revenge was directed at Gleizes-his nemesis from the 1912 Salon des Indépendants - and too bad if its real victim would be Pach, with collateral damage done to Glackens \& Co., the Ash Can School alumni eager to obtain Duchamp's endorsement for their alternative yet profoundly academic project. Pach had a falling out with Duchamp over the R. Mutt affair. ${ }^{59} \mathrm{He}$ must have known or suspected that Duchamp was the culprit; he felt rightly betrayed, for Duchamp had been ungrateful, to say the least. It was Pach who really rehabilitated the Nude Descending a Staircase (No. 2) by co-opting it for the Armory Show; it was Pach who placed several of Duchamp's paintings in the first and third exhibitions 
of contemporary French art at the New York Carroll Galleries, in December 1914 and March 1915; it was Pach who greeted Duchamp at the dock when he disembarked the Rochambeau in July 1915 after its trans-Atlantic journey from Bordeaux; and it was Pach who introduced him to the Arensbergs that very same day. There were plenty of reasons for Pach to be upset and to feel betrayed. The rift between him and Duchamp lasted about a year and caused quite a strain on Duchamp's brothers, as we know from a letter Raymond wrote to Pach in May 1918, saying: "I am really glad the estrangement period between Marcel and you is over. I was sure it wouldn't last, but suffered from it." 60

There has apparently never been a similar estrangement period between Marcel and Gleizes. He and his wife Juliette arrived in New York from Barcelona in October 1915, and Duchamp started frequenting them socially soon thereafter. In the month and a half straddling the R. Mutt affair, he dined with Gleizes no less than four times, and there is no record that their relations were less than cordial.61 But that proves only that Duchamp could be exquisitely polite in society and was able to silence his personal feelings and artistic judgments when brushing sides with esteemed colleagues whom he secretly-and not so secretly-did not esteem that much. I wonder what Gleizes must have thought of Duchamp's friendship with Picabia, who had dubbed him and Metzinger "the Bouvard and Pécuchet of Cubism" and had singled him out as the "Judge of the Cubist Court." And I wonder if Gleizes knew of the interview Duchamp gave to Arts and Decoration for its September 1915 issue, in which he scoffed:

They call Picasso the leader of the cubists but he is not a cubist strictly speaking. He is a cubist to-day something else tomorrow. The only real cubists to-day are Gleizes and Metzinger. But that word Cubism means nothing at all-it might just as well, for the sense it contains, have been policarpist. An ironical remark of Matisse's gave birth to it. Now we have a lot of little cubists, monkeys following the motions of the leader without comprehension of their significance. Their favorite word is discipline. It means everything to them and nothing. 62

Duchamp could be the most congenial companion at the dinner table and save his vitriol for other outlets. I am therefore not entirely convinced when Tomkins writes: "It was perfectly within Duchamp's nature to dismiss the anxious careerist in Gleizes without losing his affection for the man. Duchamp 
did not hold grudges." 63 I think, on the contrary, that he was capable of nurturing cold-blooded revenge underneath the veneer of his charming politeness, and that Gleizes and his authoritarian theories was a privileged target. Certainly, Duchamp did not conjure talionism as an artistic "ism" out of thin air. It doesn't really matter if it was Pach, Gleizes, or Duchamp who proposed that the new artists' society be modeled after the Société des Artistes Indépendants. What matters, I think, is that none of them warned the founding members of a loophole in the statutes of the French Société that could easily have been avoided by a small addition in the statutes of its American carbon copy. The additional clause could go either way: it could stipulate that under no circumstance should the hanging committee have jury power, not even in cases of licentious works or obvious hoaxes, such as the canvas painted by a donkey that remained on show at the 1910 Indépendants even after the hoax was revealed. ${ }^{64}$ Or it could make special provision for such exceptional cases and give the hanging committee censorship power, to be used at its discretion on grounds that are demonstrably non-aesthetic. It is understandable that Pach would not have thought of this, ${ }^{65}$ and that Gleizes would have preferred not to raise the issue in Duchamp's presence. (He probably never doubted the righteousness of his eviction of the Nude Descending a Staircase anyway.) Duchamp, on the other hand, could hardly have sat through several meetings at which the statutes of the Indeps were drafted without being reminded of the slap in the face he had received from Gleizes. He must have pondered whether he should warn the founders and present them with the alternative above. But he kept silent, and it is clear why: he was brooding his sweet revenge. Sweet, and very private: the purely personal satisfaction of having evened the score. Just as Duchamp made sure the Indeps would not be openly punished for their act of censorship, so he made sure Gleizes would not be shamed publicly for having censored the Nude Descending a Staircase five years earlier. Yet he also made sure that Gleizes would be privy to the revelation of the Indeps' betrayal of their principles and thus subtly reminded of his own betrayal. Here is one of those rare and precious little facts that the centennial re-visits to the Richard Mutt case have harvested, brought to my attention by Sophie Seita:

In an attempt to raise production funds the second issue of The Blind Man appeared both in a regular and deluxe edition. The latter featured a pink wrapper and was printed on fine 
imitation Japanese vellum in an edition of fifty. These copies were hand-numbered, dedicated to important people in the art world, and signed by Beatrice Wood, who published the issue under her name.

The fact of the deluxe edition is an important one, as we shall see. The little fact that got my attention here lies in what Seita added in a footnote: "The dedicatees included Gertrude Vanderbilt Whitney and 'Monsieur et Madame Gleizes' (number 7 of 50).” 66 Gleizes did get notice of the repressed scandal all right, and he must have put two and two together.

\section{CODA}

In many respects, art historians resemble detectives in a criminal investigation. The process of attribution-of an artwork or a crime-to its author is the crux of both corporations' practice. The present generation of art historians, however, is with regard to the R. Mutt affair like sleuths who know the culprit's identity in advance because they have read the detective novel in which they themselves are characters. They know how the story ends: they have the whole of Duchamp's life and works laid out before them. What they don't know, and are still investigating, and are puzzled by, because they don't fully realize they are characters in the novel they are reading, is the nature of the culprit's crime. Is it to have invented non-art and anti-art? Is it to have destroyed retinal art and made painting obsolete? Is it to have anticipated kinetic art, pop art, performance art, conceptual art? Or is it perhaps to have, singlehandedly, revolutionized the art world?

Let's have a look at $A$ Poster Within a Poster, the affiche Duchamp designed in 1963 for his first museum survey, at the age of seventy-five, at the Pasadena (now Norton Simon) Museum (Fig. 1.10). It is ostensibly addressed to the corporation of art historians; even more so is the poster within the poster: a facsimile of Wanted, a rectified readymade from 1923 that teases the corporation of art historians/detectives and challenges them to unmask the criminal. Wanted consists in a mock police advertisement, complete with mug shots and the list of aliases, including Rrose Sélavy, under which the wanted criminal "Operated Bucket Shop in New York."67 His crimes, in 1923, were scam, seduction, and deceit at the expense of the poor suckers who swallowed the bait, "HOOKE, LYON and CINQUER."68 The crimes' author was on the run. In 1963, he has been identified, the string of his aliases exposed, and his signature authenticated. The art historians/detectives who, in 


\section{at the \\ Pasadena art huseum}

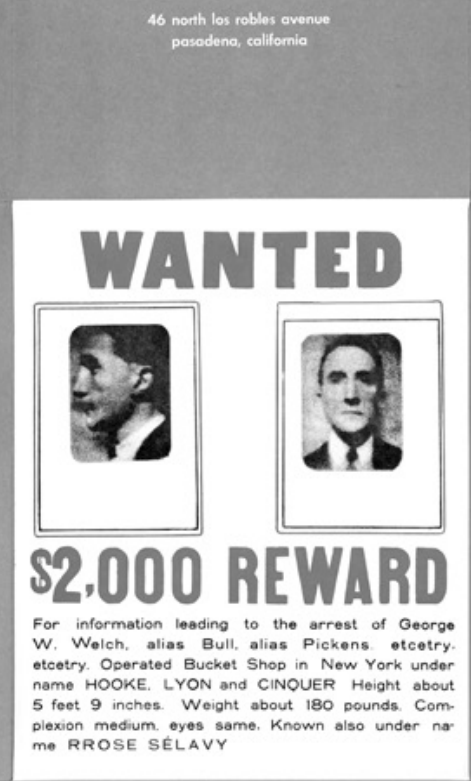

a retrospective exhibition
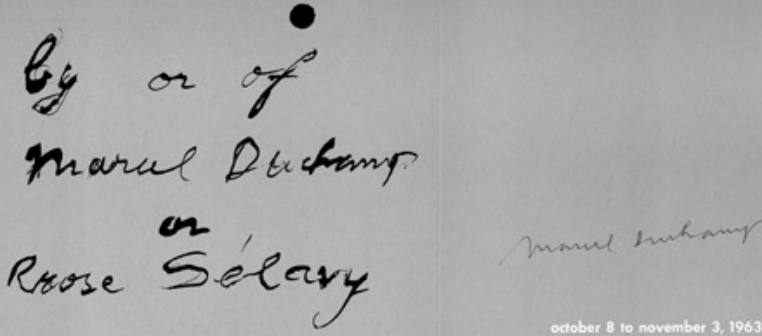

Fig. 1.10

Marcel Duchamp, "A Poster within a Poster" for "By or of Marcel Duchamp or Rrose Sélavy," Pasadena Art Museum, October 8 to November 3, 1963, 1963. Offset

lithographic exhibition poster designed by Duchamp. Sheet: $87.5 \times 69.1 \mathrm{~cm}$.

Philadelphia Museum of Art, Gift of Jacqueline, Paul, and Peter Matisse in memory of their mother, Alexina Duchamp. @ Artists Rights Society (ARS), New York / ADAGP, Paris / Succession Marcel Duchamp. 
1923, might have been searching for Rrose Sélavy, now know her real name as well as the full list of her alter egos: Victor, Totor, Sélatz, Marsélavy, Pierre Delaire, Marchand du Sel, and, of course, Richard Mutt. ${ }^{69}$ What, exactly, was the latter's crime?

The poster framing the Wanted poster announces "a retrospective exhibition by or of Marcel Duchamp or Rrose Selavy" (the italicized segment is in the artist's handwriting). "By or of" is incorrect English but once translated into French-par ou deand translated back-by or from-makes perfect sense. Duchamp, who had used the French expression for the Boites-en-Valise (they were inscribed "de ou par Marcel Duchamp ou Rrose Sélavy”) and was a master at bilingual punning, knew that the preposition "de" could mean "from" as well as "of." He would repeat that bilingual pun in the title of his 1965 exhibition, Not Seen and/or Less Seen of/by Marcel Duchamp/Rrose Sélavy 1904-64: Mary Sisler Collection, at the Cordier \& Ekstrom Gallery, in New York. And it must be noted that his first New York readymade, the snow shovel inscribed In Advance of the Broken Arm, was signed "(from) Marcel Duchamp 1915" rather than "by Marcel Duchamp” or simply "Marcel Duchamp (Fig. 5.2)."70

In The Blind Man, no such word game: the caption identifying the author of the object in Stieglitz's photo is "Fountain by R. Mutt." But what about The Blind Man itself? The magazine is supposed to have been written by its readers; the editorial is unsigned; Louise Norton, not Duchamp, is the author of "The Buddha of the Bathroom," the article in Mutt's defense that starts right under the editorial; and unlike the snow shovel, the Chocolate Grinder on the cover is soberly captioned "Marcel Duchamp." Nothing in the magazine is by Duchamp, but everything in the magazine emanates from Duchamp. He is the origin or the originator, the organizer, the ringmaster, the puppeteer who pulls all the strings, the sender of a message destined to posterity and particularly addressed to the corporation of art historians. In 1963 attribution - the basic business of detectives and art historianswas no longer at issue for the recipients of A Poster Within a Poster. The wanted criminal had been found and Duchamp's authorship of Fountain established long ago: the preposition "by" had released its secrets. Today, fifty-five years later and a good century after the affair, the preposition "of"-meaning "from"is still in need of elucidation. Wider in scope than "authorship," "agency" is the word I've used to speak of the repetition of "by" in the three captions to Stieglitz's photo. It is a word that fits "from" equally well, provided Fountain is viewed not as a work of art 
that has an author but rather as a message that has a sender and intended receivers.

The existence of a deluxe edition of The Blind Man No. 2 is the writing on the wall. To request funds from wealthy donors in order to publish a pamphlet protesting against an act that most of them would have approved is strange enough. To publish it too late for the protest to have any effect and still expect their financial help is even more bizarre. And to bait them with the prospect of holding a collector's item verges on the ludicrous. One wonders who among the "important people in the art world" to whom the deluxe edition was dedicated might have answered the call, and one comes up with the one name Sophie Seita mentions besides "Monsieur et Madame Gleizes": the socialite and academic sculptor Gertrude Vanderbilt Whitney. As an intelligent woman cursed by her social status and longing for the bohemian lifestyle of artists, she was sympathetic to the Independents. As the comfortably married Mrs. Harry Payne Whitney, she appeared on the list of twelve guarantors who backed the Society's first exhibition. And as a sculptor of some renown, she participated in the show with her already celebrated Titanic Memorial. She helped fund the publication of The Blind Man No. 2 probably not knowing what its content would be. Other sponsors might also have contributed, thinking that The Blind Man would deliver on its promise that the second number publish the readers' reactions to the show. It's a safe bet that no one among them realized that they were part of a plot emanating from Duchamp, the originator, the organizer, the ringmaster, the puppeteer who pulled all the strings. They were pawns in Duchamp's game and in no way the real addressees of the editorial that revealed "The Richard Mutt Case," with Stieglitz's photo for proof. Lest the regular edition of The Blind Man No. 2 disappear and be forgotten, the deluxe edition was Duchamp's way to hedge his bets that at least a few copies of the magazine would survive and land Fountain in art history books.

There it is now, its place as secure as the Sistine Chapel but the reasons for its place still mysteriously paradoxical. As I wrote in Kant after Duchamp:

Duchamp's most celebrated readymade-perhaps his most celebrated work-is an object that has disappeared, that practically no one has seen, that never stirred up a public scandal, about which the press at the time never spoke, which never figured in the catalogue of the Independents' Show but made it into a discreet Salon des Refusés, and whose very existence could be doubted were it not for Stieglitz's photograph. ${ }^{71}$ 
Not only is Fountain securely at home in art history books, but the scholarship about it fills bookshelf upon bookshelf. By and large, the centennial harvest of scholarly works on Fountain demonstrates the exhaustion of ambitious interpretive readings and an obsessive, petty focus on undiscovered or unexploited little facts. I must confess that I have read them with delight because I, too, was in need of facts, little or big but as hard as possible, in order to double-check the interpretive reading of Fountain I shall soon propose. ${ }^{72}$ Duchamp scholars are at a crossroad: they can choose, as many already have, to be scribes parsing every comma in the Duchamp master narrative, at the risk of appearing as Alexandrian hair-splitters to outsiders. Or they can embrace new hypotheses and new heuristic frames for their questions. As long as the frame of Duchamp scholarship is defined by the "by" question, settled long ago, we can hope no more than to unearth little facts that might make the story more savory but will not change it. The pretension to upset and revamp the "by" question with a new, provocative answer such as the re-attribution of Fountain to the Baroness Elsa von Freytag-Loringhoven, is symptomatic of the exhaustion of the "by" question, but nothing more. ${ }^{73}$ In an era when truly fake news accuses true news of being fake news, the distasteful success of said re-attribution is not really a surprise. All the more reason, I'd say, to dismiss it as factually unsubstantiated and ideologically dubious.

I propose to shift the heuristic frame of Duchamp scholarship from the "by" question to the "from" question. As a question of attribution it, too, was settled long ago. A Poster Within a Poster made that clear: its sender/publisher is the sender/publisher of the Wanted poster and the criminal the Wanted poster was looking for. What better way of conflating "by" with "from"? What better way of insinuating that "a retrospective exhibition by or of [read from] Marcel Duchamp or Rrose Selavy" was an invitation to climb back the full list of ersatz names-Marsélavy, Sélatz, and company-to the one alias that inaugurated the series, Richard Mutt? And what better way of inciting us, art historians, to respond to that invitation by dropping the "by" question in favor of the "from" question? For example: as dictated by the answer to the "by" question, the caption "Fountain by R. Mutt" reads "Fountain by M. Duchamp." Nothing new under the sun. From the point of view of the "from" question, it translates as “The Richard Mutt Case (received) from Marcel Duchamp.” A lot new under the sun. Indeed, the fountain has no existence outside the Richard Mutt case-the affair-and the affair no existence outside "The Richard Mutt Case" - the editorial. Marcel Duchamp 
is just the guy who orchestrated the editorial, the guy we got the news of the affair from.

Where there is a "from" there is a "to." Where there is a sender there are receivers, some intended, some not. I have no doubt that the corporation of art historians was the intended receiver of the double page of The Blind Man that recorded and made public the Independents' act of censorship. But I shall not attempt to divine what Duchamp's further intentions were when he wagered that The Blind Man-or at least the deluxe edition-would someday reach its addressees. Nor shall I second-guess whether Duchamp had any idea of the mass of unintended receivers who would pick up his message as if it had been addressed to them personally. Copies of The Blind Man No. 2 were scattered to the winds, after all. To paraphrase Lawrence Weiner, one of the most intelligent among the many artists who acknowledged receipt of Duchamp's message as if it had been addressed to them personally: The artist may respond to the message. The message may be answered. The message need not be replied to. Each being equal and consistent with the intent of the sender, the decision as to condition rests with the receiver upon the occasion of receivership. ${ }^{74}$ 
1 Beatrice Wood, "Work of a Picture Hanger," The Blind Man 1 (April 10, 1917): n.p.

2 Michael Taylor, "Blind Man's Bluff: Duchamp, Stieglitz, and the Fountain Scandal Revisited," in Taylor, Marcel Duchamp The Great Hidden Inspirer (Berlin: Hatje Cantz, 2017), 120.

3 We must trust the Ephemerides assembled by Jennifer Gough-Cooper and Jacques Caumont to be entirely factual, which is unlikely, in order to completely quench the temptation to speculate. The entry for June 3, 1918 mentions that Roché went to Duchamp's studio (he had the key) and, finding the disarray beautiful, took with his Kodak photographs of different corners of the room. There are two photos in which the urinal appears, one of which has the ghost-like figure. See Gough-Cooper and Caumont, "Ephemerides on and about Marcel Duchamp and Rrose Sélavy," in Marcel Duchamp (Milan: Bompiani, 1993), entry for June 3, 1918.

4 William Camfield, Marcel Duchamp: Fountain (Houston: Houston Fine Art Press, 1989).

5 Henri-Pierre Roché remembers that the organizers thwarted attemps to have Beatrice Wood and a woman friend parade in front of the entrance with huge posters advertising The Blind Man, or to have a "pretty girl" sell copies by the cash to people buying their tickets. Eventually, a pile of magazines was left on a table untouched, and a bookseller friend offered to sell some in his bookstore. See Roché, Victor, one of the four volumes of the catalogue of the Duchamp retrospective at the Pompidou Center in 1977, ed. Jean Clair (Paris: Centre National d'Art et de Culture Georges PompidouMusée d'Art Moderne, 1977), 32-33.

6 François Truffaut's 1962 film, Jules et Jim, was adapted from Henri-Pierre Roché's eponymous 1953 novel, which itself was a romanticized recollection of Roché's relationship with his Austrian friend, Franz Hessel, and his wife, Helen Grund. There are episodes in the film that resemble Roché's quasi-ménage à trois with Beatrice Wood and Duchamp.

7 Sophie Seita has emphasized the community-based and community-building raison d'être of The Blind Man and other little magazines, such as The Ridgefield Gazook and Rongwrong, circulating in New York at the time. S. Seita, "The Blind Man Sees the Fountain," in the facsimile re-edition of The Blind Man (New York: Ugly Duckling Presse, 2017).

8 The first number of The Blind Man initially did not mention this address. It had to be added manually with the help of a rubber stamp so that the people candidly attracted by the invitation to contribute to the second number would know where to send their piece. This oversight is in my opinion a clear sign that the magazine's purported appeal to the public's opinion was a red herring.

9 Ephemerides, entry for April 2, 1917.

10 "I Propose to Strain the Laws of Physics," Interview with Francis Roberts, Art News, 67, 8 (December 1968).

11 Kirk Varnedoe and Adam Gopnik, High and Low: Modern Art and Popular Culture (New York: Museum of Modern Art, 1990), 277. See also Matthew Armstrong, "Searching High and Low," Museum of Modern Art Quarterly (fall 1990): 4-7.
12 Varnedoe and Gopnik, High and Low, 277-78. The J. L. Mott Iron Works catalogue of 1914, Modern Plumbing, states: "Our showrooms exemplify the possibilities and perfection of modern plumbing of the highest class, the exhibits being unequalled and eclipsing all our previous efforts. The bathrooms, artistic and beautiful, novel and complete, are a revelation. They demonstrate what can be accomplished by the proper treatment of tiling with our porcelain, vitreous and other high-grade ware." Quoted by Glyn Thompson, Duchamp's Urinal? The Facts Behind the Façade (Leeds: Wild Pansy Press, 2015, e-book), 31.

13 Varnedoe and Gopnik, High and Low, 278.

14 The cartoon, by Wolcott, is captioned: "In the slum district of New York City I saw a lavatory as the entire window exhibit, but it was a puller, for the denizens of that quarter stopped by the scores to look at it." D. L. Hanson, "Window Displays with 'Pulling' Power Create Sales," Plumber's Trade Journal, Steam and Hot Water Fitters' Review (1 September 1917): 282. Reproduced in Varnedoe and Gopnik, High and Low, 278.

15 Sanitary Pottery 1, 3 (June 1909): cover. Reproduced in Ezra Shades, “'Decadent Plumber's Porcelain': Craft and Modernity in Ceramic Sanitary Ware," in "R. Mutt: Writings About Marcel Duchamp's Fountain (1917) and its Aftermath," eds. Garth Clark and Marie Claire Bryant, Ostracon Journal of Criticism 3 (October 2017): 215.

16 Sanitary Pottery 8, 8 (December 1916). Reproduced in Shades, “'Decadent Plumber's Porcelain'," 230.

17 Sanitary Pottery. 7, 3 (July 1915), cover. Reproduced in Shades, “'Decadent Plumber's Porcelain'," 213.

18 "This porcelain tribute was bought cold in some plumber shop (where it awaited the call to join some bathroom trinity) and sent in... When it was rejected Marcel Duchamp at once resigned from the board. Stieglitz is exhibiting the object at '291' and he has made some wonderful photographs of it. The photographs made it look like anything from a Madonna to a Buddha." Carl Van Vechten, undated letter to Gertrude Stein, in The Letters of Gertrude Stein and Carl Van Vechten, 1913-1946, ed. Edward Burns (New York: Columbia University Press, 1986), 58-59.

19 William B. M'Cormick, "Surely Useful and Purely Decorative: Both Have Their Place in Novel "Art' Show," New York Press (22 February 1915). Quoted by Ezra Shades, “'Decadent Plumber's Porcelain'," 233-34.

20 The Deutscher Werkbund, founded in 1907 for the cultural and artistic renovation of the German industry, made the word Qualität key to its propaganda. On Duchamp's stay in Munich, the Gewerbeschau, and Kunstgewerbe in general, see chapter 5 of my book, Pictorial Nominalism, On Marcel Duchamp's Passage from Painting to the Readymade, transl. Dana Polan (Minneapolis: University of Minnesota Press, 1991), 96-118.

21 Camfield, Marcel Duchamp: Fountain, 24, n. 22, 53, n. 66; Varnedoe and Gopnik, High and Low, 276-77; Thompson, Duchamp's Urinal?, 89-102; Calvin Tomkins, Duchamp: A Biography (New York: Museum of Modern Art, 2014, revised edition), 178. Thompson, who has located two extant copies of the flat-back lipped Bedfordshire urinal and even bought one, claims 
he identified the model correctly. But, as Francis Naumann pointed out to me, Thompson's model is missing the raised rim on which Duchamp inscribed the signature and date, as proved by a photo Naumann showed me of the same urinal Thompson located at the Magic Chef Mansion in Saint Louis. Thompson has showed his disingenuousness by not yielding to the evidence. Moreover, his reattribution of Fountain to the Baroness Elsa von Freytag-Loringhoven is factually unsubstantiated and argued with spurious rationales.

22 Paul B. Franklin, “Object Choice: Marcel Duchamp's Fountain and the Art of Queer Art History," in "R. Mutt: Writings About Marcel Duchamp's Fountain (1917) and its Aftermath," 157-58. Franklin found the model he has elected in the J. L. Mott Iron Works' Catalogue 'G' (New York: 1888), 232.

23 In a conversation with Francis Naumann and Mike Bidlo, Arthur Danto said: "As a philosopher, seeing things from the perspective of identity, it doesn't seem to me that all the urinals have to be tokens of the same material typethey only have to be tokens of the type 'urinal' of which there is a great variety. Material identity is, I think, an art historian's criterion. But they are not used to dealing with thoughts of the kind Duchamp was driven by. My view is that if Fountain is an idea which is embodied in that object, it is consistent that it could be embodied in any object which serves the same function, whether it's made of stainless steel or porcelain or whatever, and the precise replication is not entailed by the idea of what he did." "Dialogue with Mike Bidlo, Arthur Danto, Francis Naumann," in "R. Mutt: Writings About Marcel Duchamp's Fountain (1917) and its Aftermath," 104.

24 Camfield, Marcel Duchamp: Fountain, 26.

25 Camfield, 26 and 27.

26 Beatrice Wood, I Shock Myself, (Ojai, CA: Dillingham Press, 1985), 30, quoted by Camfield, Marcel Duchamp: Fountain, 33.

27 Wood has written several accounts of the story of Fountain but all of them many years after the events. According to Camfield, the earlier version appeared in a letter Wood wrote to Louise Arensberg on August 10, 1949. See Camfield, Marcel Duchamp: Fountain, 25, n. 24.

28 Taylor, "Blind Man's Bluff," 45.

29 Stieglitz, "My dear Blind Man," The Blind Man 2 (May 1917): 15.

30 Stieglitz, letter to McBride, 19 April 1917. Quoted by Francis Naumann, "The Big Show, The First Exhibition of the Society of Independent Artists, Part I," Artforum (February 1979): 39, n. 22.

31 Ephemerides, entry for April 9, 1917.

32 Ira Glackens, William Glackens and the Ash Can Group (New York: Crown, 1957), 187.

33 Francis Naumann, “Fountain's Furtive Fate or Farfetched Fiction?" in Bonnie Clearwater, Some Aesthetic Decisions, A Centennial Celebration of Marcel Duchamp's “Fountain," exh. cat. (Fort Lauderdale: NSU Art Museum/Skira, 2017), 22.

34 Most of these stories are examined by Camfield, Marcel Duchamp: Fountain, 24-35.

35 Rockwell Kent, It's Me, O Lord (New York: Dodd, Mead \& Co., 1955), 316.

36 Beatrice Wood, unpublished diary, April 13, 1917.
Quoted by Camfield, Marcel Duchamp: Fountain, 33.

37 Calvin Tomkins, Duchamp: A Biography, 183.

38 Announcement titled "The Society of Independent Artists, Inc.," undated, in the Archives of the Société Anonyme, Beinecke Rare Book and Manuscript Library, Yale University; quoted in part by Camfield, Marcel Duchamp: Fountain, 19. The same passage appears in the foreword to the catalogue of the 1917 exhibition. See Clark S. Marlor, The Society of Independent Artists (Park Ridge, NJ: Noyes Press, 1984), 7.

39 Bylaws of the Society of Independent Artists, 1916. Quoted by Marlor, The Society of Independent Artists, 81.

40 Quoted by Francis Naumann, "The Big Show, The First Exhibition of the Society of Independent Artists, Part II, The Critical Response," Artforum 17 (April 1979): 49.

41 See Hugo Ball, Flight Out of Time, A Dada Diary, ed. John Elderfield, Berkeley, University of California Press, 1996.

42 Marlor, The Society of Independent Artists, 8.

43 Royal Cortissoz, "The Danger of Mixing Democracy and Art, What the Society of Independent Artists Has Done to Discredit the Old Idea of an American Salon," New York Tribune (Sunday April 13, 1917).

44 See for example Peter Bürger, Theory of the Avant-Garde (Minneapolis: University of Minnesota Press, 1984).

45 Mina Loy, "Pas de commentaires! Louis M. Eilshemius," The Blind Man 2 (May 1917): 12.

46 Dreier to Glackens, Quoted by F. Naumann, "The Big Show, Part I," 39, note 16.

47 "Une de mes amies sous un pseudonyme masculin, Richard Mutt, avait envoyé une pissotière en porcelaine comme sculpture." Affectionately, Marcel. The Selected Correspondence of Marcel Duchamp, eds. Francis Naumann and Hector Obalk (Ghent: Ludion, 2000), 47 (translation modified). According to Irene Gammel, the "female friend" in question might have been the Baroness Elsa von Freytag-Loringhoven, who would have given Duchamp the urinal as a sculpture. See Gammel, Baroness Elsa: Gender, Dada, and Everyday Modernity, 222-224. A collaboration between Duchamp and the Baroness is not entirely to be excluded, for she did indeed collaborate with Morton Schamberg on God (1917), a "semi-readymade" assemblage of a carpenter's miter box and a plumbing trap whose affinity with Fountain is evident. But to conclude from Duchamp's letter to his sister that the female friend in question was the Baroness is an unwarranted leap of faith. It is much more likely that she was Louise Norton, whose address appears on the registration card attached to the urinal and visible in Stieglits's photograph. Someone indeed had to take charge of sending or bringing the urinal physically to the Grand Central Palace, since Duchamp could hardly have done it himself without revealing Mutt's identity, and Louise Norton, who wrote the article that follows the editorial in The Blind Man No. 2, "Buddha of the Bathroom," is the most likely candidate.

48 Under No. 50, the catalogue of the Bourgeois Galleries simply lists "Two Readymades" and does not identify them. The press did not report the matter, and it is therefore unlikely that the directors of the Independents were in the know. To Marcel Jean, Duchamp provided an interesting piece of information, which might explain why 
the two readymades went unnoticed: he said that they were exhibited in an umbrella stand at the entrance to the show. See Marcel Duchamp, Letters to Marcel Jean (Munich: Silke Schreiber Verlag, 1987), 77.

49 See W.K. Wimsatt and Monroe C. Beardsley, "The Intentional Fallacy," Sewanee Review n ${ }^{\circ}$ 54, 1946.

50 Marcel Duchamp, Duchamp du Signe, Écrits, ed. Michel Sanouillet (Paris: Flammarion, 1975), 111.

51 Salt Seller, The Essential Writings of Marcel Duchamp, eds. Michel Sanouillet and Elmer Peterson (London: Thames and Hudson, 1975), 78.

52 "There's so much in that little note. This [the Gray version] you can read and move on, because it doesn't mean very much. Duchamp used the word talionism. I don't need to know about French to ask: is 'retaliation' talionism? Look up the word in the dictionary and the root is the same. But talionism is the law of talion and it's an English word that is perfectly good. And you think: how does an eye for an eye and a tooth for a tooth come into this?" Richard Hamilton, quoted by Rick Poynor, "Typotranslation," Eye 38, 10 (2000); http://www. eyemagazine.com/feature/article/typotranslation.

53 The Biblical "law of talion" is mentioned in Exodus 21, Leviticus 24:20, and Deuteronomy 19:21.

54 On these various "isms," see André Gervais, La raie alitée des faits (Montreal: Hurtubise, 1984), 6-8

55 Publication of Du Cubisme was announced in the Revue d'Europe et d'Amérique on March 1st, 1912, then in the Gazette des Beaux-Arts on the occasion of the Salon de Indépendants in April, and again in Paris-Journal on October 26, but the book was probably issued late November or early December. See the Documentary Chronology in William Rubin, Picasso and Braque, Pioneering Cubism (New York: Museum of Modern Art, 1989), 389; 409.

56 Tomkins, Duchamp: A Biography, 80.

57 Tomkins, 80.

58 Tomkins, $161 ; 163$.

59 Laurette E. McCarthy, "Marcel Duchamp, Walter Pach, and the Urinal," in Some Aesthetic Decisions: A Centenary Celebration of Marcel Duchamp's "Fountain," ed. Bonnie Clearwater (Milan: Skira, 2017), 27-37.

60 Laurette E. McCarthy, 33.

61 See Ephemerides, entries for March 19, March 25, April 25, and May 1st, 1917; in addition, Duchamp saw Gleizes on February 22, April 17, and July 28 , the latter at a party thrown by the Stettheimer sisters at their summer residence for Marcel's birthday.

62 "A Complete Reversal of Art Opinions by Marcel Duchamp, Iconoclast," Arts and Decoration (September 1915). See Ephemerides, entry for September 1, 1915.

63 Tomkins, Duchamp: A Biography, 162.

64 The painting Sunset over the Adriatic won praise from critics when it was displayed at the Salon des Indépendants in Paris in March 1910. It was said to be the work of J.R. Boronali, proponent of a new school of painting called "excessivism." But after a few days the truth was revealed. Boronali was actually a donkey named Lolo who had "painted" by having a brush tied to his tail. The stunt was dreamed up by art critic Roland Dorgelès as a way to play a joke on his Impressionist painter friends.
See http://hoaxes.org/archive/permalink/ boronali_donkey_artist

65 Pach must have thought of such provision in retrospect, however. In 1936, John Sloan sent Alfred Barr a letter the draft of which had been handwritten by Pach to protest against Barr's misrepresentation of the Independents in the R. Mutt affair as a jury. Speaking of the administrative duties of the directors, Pach wrote: "Their function in every case is distinct from that of a jury, which is a body that passes on aesthetic merits. [...] By covering up under inoffensive words the whole question we had to face, you change the issue and put us in the position of rejecting an exhibit offered as a work of art when, as you must know, we were dealing with a matter totally unrelated with art." Quoted by McCarthy, "Marcel Duchamp, Walter Pach, and the Urinal," 34-35.

66 Sophie Seita, "The Blind Man Sees the Fountain," 11-12.

67 "As defined by the U.S. Supreme Court, a bucket shop is 'an establishment, nominally for the transaction of a stock exchange business, or business of similar character, but really for the registration of bets, or wagers, usually for small amounts, on the rise or fall of the prices of stocks, grain, oil, etc., there being no transfer or delivery of the stock or commodities nominally dealt in.' [...] Typically the criminal law definition refers to an operation in which the customer is sold what is supposed to be a derivative interest in a security or commodity future, but there is no transaction made on any exchange. The transaction goes 'in the bucket' and is never executed. Because no trading of actual securities occurs, the customer is essentially betting against the bucket shop operator in a game based on abstract security prices. [...] The bucket shop's exchange is a fiction, which the parties agree to imagine as following the events occurring in a real exchange. Alternatively, the bucket shop operator literally 'plays the bank,' as in a gambling house, against the customer." See https://en.wikipedia.org/wiki/Bucket_shop_(stock_ market). Bucket shops were often in the news in 1923, as William S. Silkworth, a questionable figure who was president of the Consolidated Stock Exchange (the New York Stock Exchange's less reputable rival) and who "operated several bucket shops, and had a hand in many shady deals of the period," was ousted in june 1923 after a financial scandal. It is amusing to imagine Duchamp modeling his criminal aliases on Silkworth, who, we are told, "was also a fine salesman, a man of considerable charm, and an excellent publicity director for his market." Robert Sobel, AMEX, A History of the American Stock Exchange 1921-1971 (Washington, DC: Beard Books, 2000), 29.

68 The text on the poster goes as follows: WANTED $\$ 2,000$ REWARD For information leading to the arrest of George W. Welch, alias Bull, alias Pickens, etcetry, etcetry. Operated Bucket Shop in New York under name HOOKE, LYON and CINQUER. Height about 5 feet 9 inches. Weight about 180 pounds. Complexion medium, eyes same. Known also under name RROSE SELAVY.

69 As already noted, Victor is the nickname Roché gave to Duchamp in 1917, and Totor its diminutive; Sélatz is the name Duchamp signed a telegram to Picabia in December 1922; Marsélavy is the signature on at least two letters, 
one to the Arensberg (November 1921) and one to Picabia (January 1923); Pierre Delaire is a character, modeled on Duchamp, in a novel Henrietta Stettheimer published in 1923 under the nom-de-plume Henri Waste; finally, the spoonerism Marchand du Sel was coined by Robert Desnos in October 1922 and became the title of Duchamp's writings collected by Michel Sanouillet in 1958. See Gervais, La raie alitée des faits, 28-30.

70 See Calvin Tomkins, Duchamp: A Biography (New York: MoMA, 2014, revised edition), 153-154.

71 Thierry de Duve, Kant after Duchamp (Cambridge, MA: MIT Press, 1996), 411.

72 I shall do so in a forthcoming book titled Duchamp's Telegram.

73 See Irene Gammel, Baroness Elsa: Gender, Dada, and Everyday Modernity-A Cultural Biography (Cambridge, MA: MIT Press, 2002), 222-224.

74 I am paraphrasing the statement which Lawrence Weiner devised in 1969 to accompany the presentation of his works: "The artist may construct the piece. The piece may be fabricated. The piece need not be built. Each being equal and consistent with the intent of the artist, the decision as to condition rests with the receiver upon the occasion of receivership." 